\title{
Simulasi Uji BUSS (Baru, Unik, Seragam Stabil) Enam Varietas Nenas (Ananas comosus L. Merr.).
}

\author{
Simulation Tests for Novelty, Distinctness, Uniformity, and Stability (nDUS) for \\ Six Pineapple (Ananas comosus L. Merr) Varieties
}

\section{Poetri Agustine Aryawati dan Sobir*}

Departemen Agronomi dan Hortikultura, Fakultas Pertanian, Institut Pertanian Bogor (Bogor Agricultural University), Jl. Meranti, Kampus IPB Darmaga, Bogor 16680, Indonesia. Telp \& Faks. 62-251-8629353 e-mail agronipb@indo.net.id

*Penulis untuk korespondensi: $\underline{\text { sobir@ipb.ac.id }}$

Disetujui 24 Desember 2013/ Published Online 10 Januari 2014

\begin{abstract}
The objective of this experiment was to elucidate the characters of the distinctness, uniformity and stability of the six varieties of pineapples, as simulation DUS test important for the Plant Variety Protection Rights application. The experiment was conducted at Pasir Kuda experimental field, Bogor, West Java. The experimental materials consisted of five candidates varieties are Dole 14, P-1972, Mayan Gold 01, Champaka, Pasir Kuda and Subang as reference variety. The result showed that six varieties can be deemed to be dictinct. The distinctness between candidates varieties with reference variety consist of seven characters on the plant, six characters on the leaves, four characters on the flower, nineteen characters on the peduncle and fruit. Six varieties can be deemed to be uniform and stable. Off-type are found only in one plant with two crown Subang variety. The number of off-types are still under uniformity standard.
\end{abstract}

Keywords: distinctness, pineapples, protection of variety.

\section{ABSTRAK}

Penelitian ini bertujuan untuk mengetahui karakter keunikan, keseragaman, dan kestabilan dari enam varietas nenas sebagai simulasi UJI BUSS untuk permohonan hak Perlindungan Varietas Tanaman. Penelitian dilaksanakan di Kebun Percobaan Pasir Kuda, Bogor, Jawa Barat. Bahan percobaan terdiri dari enam varietas nenas yang terdiri dari varietas yang diuji yaitu Dole 14, P-1972, Mayan Gold 01, Champaka, Pasir Kuda dan varietas referensi yaitu varietas Subang. Hasil penelitian menunjukkan bahwa keenam varietas dapat dinyatakan berbeda. Perbedaan antara varietas kandidat dengan varietas referensi terdapat tujuh karakter pada bagian tanaman, enam karakter pada bagian daun, empat karakter pada bagian bunga, sembilan belas karakter pada bagian tangkai buah dan buah. Keenam varietas dapat dinyatakan seragam dan stabil. Tipe simpang hanya ditemukan pada satu tanaman dengan dua crown pada varietas Subang, jumlah tipe simpang yang ditemukan masih dibawah batas standar keseragaman.

Kata kunci: keunikan, nenas, perlindungan varietas.

\section{PENDAHULUAN}

Nenas (Ananas comosus L. Merr.) merupakan salah satu buah dengan produksi tertinggi di Indonesia setelah buah pisang, mangga dan jeruk. Produksi nenas mencapai 1275490 ton pada tahun 2012 dengan produksi tertinggi mencapai 1558196 ton pada tahun 2009 (Deptan, 2013). Produksi yang tinggi ini disebabkan tanaman nenas mempunyai syarat tumbuh yang sesuai dengan agroklimat di
Indonesia. Pada tahun 2009, 79 plasma nutfah telah dikumpulkan dan dihasilkan 180 persilangan (Sobir dan Naibaho, 2010). Nenas berpotensi menjadi komoditas andalan ekspor Indonesia. Nilai ekspor buah nenas pada tahun 2012 mencapai USD 132015559 (Deptan, 2013). Rasanya yang segar, bergizi, dan beraroma khas saat dikonsumsi menjadikan buah nenas banyak disukai masyarakat luas.

Data produksi nenas dalam FAOSTAT (2013) menunjukkan Indonesia menjadi negara 
peringkat keenam terbesar dalam produksi nenas dunia pada tahun 2011. Indonesia bersaing dengan negara penghasil nenas terbesar lainnya seperti Brazil, Thailand, Philipina, Costa Rica, dan China. Varietas unggul sangat diperlukan dalam upaya meningkatkan daya saing hasil produktivitas dan kualitas buah nenas di Indonesia. Upaya peningkatan produktivitas dan kualitas sangat dipengaruhi oleh keberhasilan dalam memperbaiki potensi genetik tanaman. Oleh karena itu, individu atau badan usaha yang bergerak di bidang pemuliaan tanaman harus diberi penghargaan bagi mereka yang telah menghasilkan varietas tanaman yang baru, unik, seragam, dan stabil. Salah satu penghargaannya adalah dengan memberikan hak PVT (Perlindungan Varietas Tanaman) sebagai perlindungan untuk pemulia.

Penelitian dilakukan untuk mengetahui karakter keunikan, keseragaman, dan kestabilan dari enam varietas nenas sebagai simulasi UJI BUSS untuk permohonan hak Perlindungan Varietas Tanaman, mengidentifikasi tanaman contoh dan penyempurnaan Panduan Pelaksanaan Uji (PPU) yang digunakan. Uji BUSS (Baru, Unik, Seragam, Stabil) merupakan metode dalam mengidentifikasi karakter suatu varietas tanaman berdasarkan tanda-tanda morfologi baik kualitatif, kuantitif maupun pseudokualitatif dengan bantuan pedoman dari PPI (Panduan Pengujian Individual) untuk tingkat nasional dan UPOV (International Union for the Protection of New Varieties of Plants) untuk tingkat International.

\section{BAHAN DAN METODE}

Penelitian ini telah dilaksanakan di Kebun PKHT Pasir Kuda, Bogor, Jawa Barat dan Laboratorium Pasca Panen Departemen Agronomi dan Hortikultura, Fakultas Pertanian, IPB. Penelitian telah dilaksanakan pada bulan Oktober 2012 hingga Maret 2013.

Bahan yang digunakan adalah 6 varietas nenas yaitu Dole 14, P-1972, Mayan Gold 01 (MG 01), Champaka (CMPK), Pasir Kuda (PK) dan Subang (DS), pupuk NPK, ethrel, pestisida, bahan uji total asam terlarut. Alat yang digunakan terdiri dari peralatan budidaya, alat tulis, alat ukur, alat uji total asam terlarut, pisau, label, kain abuabu, kamera dan Guidelines UPOV Pineapple Proj 10.

Metode penelitian ini menggunakan Rancangan Kelompok Lengkap Teracak (RKLT) faktor tunggal dengan tiga ulangan. Setiap ulangan terdiri atas 9 tanaman nenas, diambil 4 tanaman contoh setiap ulangan. Jumlah tanaman nenas yang ditanam adalah 27 tanaman per varietas.

Pengamatan dilakukan terhadap tanaman nenas yang berumur 18 bulan (fase vegetatif) yang berada di Kebun PKHT Pasir Kuda, Bogor, Jawa Barat. Tanaman tersebut telah ditanam pada 6 April 2011. Keenam varietas nenas yang ditanam mendapat perlakuan budidaya yang sama. Tanaman nenas ditanam dengan jarak $100 \mathrm{~cm} \mathrm{x}$ $50 \mathrm{~cm}$ pada lahan seluas $6 \mathrm{~m} \times 13.5 \mathrm{~m}$. Benih yang digunakan adalah benih anakan. Pemeliharaan yang dilaksanakan antara lain penyiangan gulma pada bedengan, selain itu dilakukan pengendalian terhadap organisme penganggu tanaman agar tanaman bebas dari hama atau penyakit.

Pemupukan dilaksanakan empat kali dengan dosis mengikuti SPO (Standar Prosedur Operasional). Induksi pembungaan dilakukan dengan pemberian ethrel dengan bahan aktif etilen. Ethrel diberikan bersama dengan urea. Urea sebanyak $30 \mathrm{~g}$ dilarutkan dalam 1 liter air kemudian dicampur dengan 0,6 ml Ethrel. Setiap tanaman mendapatkan 25-30 ml larutan yang disiramkan pada titik tumbuh.

Panen dilakukan dengan mengambil buah yang sudah menunjukkan ciri (sifat khusus) matang pohon yaitu tingkat kematangan 30\% (warna pada dasar buah berwarna kuning dan pangkal batang buah telah keriput). Pemanenan nenas dilakukan dengan memetik nenas. Nenas yang telah dipanen kemudian disimpan selama \pm 3 hari sebelum dilakukan pengamatan terhadap karakter-karakter buah.

Peubah yang diamati antara lain pada bagian vegetatif meliputi tanaman (postur tumbuh, jumlah daun, tinggi tanaman sampai pangkal daun, jumlah sucker didasar, jumlah sucker batang, ukuran sucker batang, jumlah slip, ukuran slip), daun (panjang daun, lebar daun, warna hijau diatas sisi daun, warna antosianin, kepadatan trikoma pada sisi bawah daun, keadaan marjin, duri yang dilakukan hanya untuk varietas berduri antara lain : kepadatan duri, posisi duri di marjin, warna duri, ukuran duri). Pada bagian generatif tanaman meliputi bunga (ukuran braktea bunga, warna puncak mahkota, panjang mahkota, panjang benang sari, panjang tangkai putik), tangkai (tinggi tangkai, diameter tangkai), buah (warna buah belum masak, jumlah mahkota, letak mahkota, ukuran mahkota, bentuk buah, panjang buah, diameter buah, warna utama buah, ukuran buah, ukuran mata tunas buah, profil mata buah, ketidakrataan warna mata, warna daging buah, 
diameter tengah (hati) buah, ketidakrataan warna daging, kepadatan daging, kekukuhan daging, keberseratan daging, aroma daging, keberairan daging, keasaman daging (TAT), kemanisan daging.

\section{HASIL DAN PEMBAHASAN}

\section{Karakter Vegetatif}

\section{a. Tanaman Nenas}

Tanaman nenas (Ananas comosus L. Merr.) merupakan tanaman herbacious. Keenam varietas yang ditanam pada penelitian ini termasuk dalam jenis smooth cayenne. Nenas dari jenis smooth cayenne atau cayenne Lisie mempunyai ukuran tanaman medium (80-100 cm), dengan 60-80 helai daun berwarna hijau gelap (panjang $100 \mathrm{~cm}$ dan lebar $6 \mathrm{~cm}$ ), memiliki duri kecil di ujung dan dasar daun (Chan et al., 2003). Enam varietas nenas mempunyai postur tumbuh, jumlah daun dan tinggi tanaman sampai pangkal yang berbeda. Tabel 1 menunjukkan Varietas Dole 14 mempunyai postur tumbuh yang menyebar, dengan jumlah daun yang sedikit dan tinggi tanaman ke pangkal buah yang pendek. Varietas Dole 14 memiliki postur tumbuh yang berbeda dari varietas SBG dan lainnya karena mempunyai postur tumbuh yang menyebar. Varietas P1972 dan CMPK mempunyai postur tumbuh yang semi tegak, jumlah daun yang tidak terlalu banyak dan tinggi ke pangkal dengan ukuran tinggi. Varietas MG 01 memiliki postur tumbuh semi tegak dengan jumlah daun sedikit dan tinggi tanaman dengan ukuran tinggi. Varietas PK memiliki postur tumbuh yang semi tegak dengan jumlah daun dan tinggi tanaman yang sedang. Varietas SBG memiliki postur tumbuh semi tegak, dengan jumlah daun paling banyak dan tinggi tanaman dengan ukuran tinggi.

Tabel 1. Deskripsi karakteristik tanaman nenas

\begin{tabular}{|c|c|c|c|c|c|c|c|c|}
\hline \multirow{3}{*}{ No } & \multirow{3}{*}{ Ket } & \multirow{3}{*}{ Karakter } & \multicolumn{6}{|c|}{ Hasil pemeriksaan varietas } \\
\hline & & & \multicolumn{5}{|c|}{ Kandidat } & \multirow{2}{*}{$\begin{array}{c}\text { Referensi } \\
\text { SBG }\end{array}$} \\
\hline & & & Dole 14 & P1972 & MG01 & CMPK & PK & \\
\hline \multirow{2}{*}{$\begin{array}{c}1 . \\
\text { QN } \\
(*) \\
(+)\end{array}$} & \multirow{2}{*}{$\begin{array}{l}\mathrm{VG} \\
1-\mathrm{T}\end{array}$} & Postur tumbuh & Menyebar & Semi tegak & $\begin{array}{l}\text { Semi } \\
\text { tegak }\end{array}$ & Semi tegak & Semi tegak & Semi tegak \\
\hline & & Notasi & (5) & (3) & (3) & (3) & (3) & (3) \\
\hline \multirow{3}{*}{$\begin{array}{c}2 . \\
\text { QN } \\
(+) \\
(*) \\
\end{array}$} & \multirow{3}{*}{$\begin{array}{l}\text { VG/ } \\
\text { MS } \\
1-\mathrm{T}\end{array}$} & Jumlah daun & Sedikit & Sedang & Sedikit & Sedang & Sedang & Banyak \\
\hline & & Notasi & (3) & $(5)$ & (3) & $(5)$ & $(5)$ & $(7)$ \\
\hline & & Nilai Tengah $^{\mathrm{a}}$ & $17 d$ & $23 \mathrm{c}$ & $19 d$ & $24 \mathrm{c}$ & $27 b$ & $30 \mathrm{a}$ \\
\hline \multirow[t]{2}{*}{$\begin{array}{l}20 . \\
\text { QN }\end{array}$} & \multirow[t]{2}{*}{$\begin{array}{l}\text { VG } \\
4-\mathrm{M}\end{array}$} & $\begin{array}{c}\text { Tinggi ke } \\
\text { pangkal buah }\end{array}$ & Pendek & Tinggi & Tinggi & Tinggi & Sedang & Tinggi \\
\hline & & Notasi & (3) & $(7)$ & (7) & (7) & $(5)$ & (7) \\
\hline \multirow{2}{*}{$\begin{array}{l}23 . \\
\text { QN } \\
(*)\end{array}$} & \multirow{2}{*}{$\begin{array}{l}\text { VG } \\
4-\mathrm{M}\end{array}$} & Jumlah sucker & Sedang & Banyak & Sedikit & Sedikit & Banyak & Sedang \\
\hline & & Notasi & (3) & (4) & $(2)$ & (2) & (4) & (3) \\
\hline \multirow{2}{*}{$\begin{array}{l}24 . \\
\text { QN }\end{array}$} & \multirow{2}{*}{$\begin{array}{l}\text { VG } \\
4-\mathrm{M}\end{array}$} & $\begin{array}{c}\text { Jumlah sucker } \\
\text { batang }\end{array}$ & Sedang & Banyak & Sedang & Tidak ada & Banyak & Sedang \\
\hline & & Notasi & (3) & (4) & (3) & $(1)$ & (4) & (3) \\
\hline \multirow{2}{*}{$\begin{array}{l}25 . \\
\text { QN }\end{array}$} & \multirow{2}{*}{$\begin{array}{l}\text { VG } \\
4-M\end{array}$} & $\begin{array}{l}\text { Ukuran sucker } \\
\text { batang }\end{array}$ & Sedang & Sedang & Sedang & Sedang & Sedang & Sedang \\
\hline & & Notasi & (2) & (2) & $(2)$ & (2) & (2) & $(2)$ \\
\hline \multirow{2}{*}{$\begin{array}{l}26 . \\
\text { QN } \\
(*)\end{array}$} & $\begin{array}{l}\text { VG/ } \\
\text { MS }\end{array}$ & Jumlah slip & Tidak ada & Sedang & $\begin{array}{l}\text { Sangat } \\
\text { Sedikit }\end{array}$ & Tidak ada & Sedikit & $\begin{array}{l}\text { Sangat } \\
\text { Sedikit }\end{array}$ \\
\hline & 4-M & Notasi & $(1)$ & $(5)$ & $(1)$ & $(1)$ & (3) & $(1)$ \\
\hline \multirow{2}{*}{$\begin{array}{l}27 . \\
\text { QN }\end{array}$} & VG/ & Ukuran slip & - & Sedang & Kecil & - & Kecil & Besar \\
\hline & MS & Notasi & & $(5)$ & $(3)$ & & $(3)$ & $(7)$ \\
\hline
\end{tabular}


Korelasi yang baik antara jumlah daun dan diameter tajuk dengan ukuran buah terjadi karena fotosintat yang dihasilkan lebih banyak dan efisiensi penerimaan cahaya yang baik (Nitrisari dan Sobir, 2002). Pernyataan ini terlihat pada varietas SBG yang mempunyai bobot buah yang lebih besar dibanding yang lain karena memiliki daun yang lebih banyak.

Sucker di dasar (underground suckers) merupakan anakan yang tumbuh di bagian bawah dekat akar tanaman (antara batang dan akar). Varietas yang memiliki jumlah sucker di dasar yang paling banyak adalah P1972 dan PK, sedangkan varietas CMPK dan MG 01 mempunyai jumlah yang lebih sedikit. Sucker batang (aerial suckers) merupakan anakan yang tumbuh pada batang. Pada keenam varietas terdapat sucker batang yang tumbuh paling banyak pada varietas P1972 dan PK dibandingkan varietas lain, sedangkan varietas CMPK tidak ditemukan sucker batang. Slip atau hapas merupakan anakan yang tumbuh pada tangkai atau basal buah. Slip yang ditemukan hanya pada varietas P1972 dan Varietas PK. Pada varietas MG 01 dan SBG hanya ditemukan 1 tanaman yang memiliki slip.

\section{b. Daun}

Tabel 2 pada pengamatan panjang daun menunjukkan bahwa ukuran panjang daun dari varietas referensi SBG yang berukuran sedang, varietas yang berukuran lebih pendek yaitu CMPK, MG 01 dan Dole 14 dan varietas yang berukuran lebih panjang yaitu P1972 dan PK. Data Tabel 2 pada data lebar daun menunjukkan bahwa daun varietas PK mempunyai ukuran paling lebar dari varietas yang lain dengan ratarata $5.258 \mathrm{~cm}$ dan varietas yang mempunyai daun tersempit ialah Dole 14.

Warna daun yang dimiliki dari 6 varietas nenas ini bervariasi. Varietas Dole 14 memiliki daun yang berwarna hijau muda kekuningan. Varietas P1972 memiliki warna daun hijau sedang kekuningan yang lebih gelap dari varietas Dole. Varietas MG 01, CMPK dan SBG mempunyai warna hijau yang hampir sama dengan P1972. Daun pada varietas MG 01, CMPK dan SBG memiliki kandungan antosianin yang berada pada tengah daun, namun varietas CMPK memiliki kandungan antosianin yang lebih kuat. Warna daun pada varietas PK memiliki warna daun hijau gelap (tua).

Pada daun varietas MG 01 mempunyai karakteristik yang berbeda dari varietas yang lain yaitu mempunyai piping atau margin daun. Beberapa dari jenis kultivar "smooth", epidermis bawah terlipat diujung tepi daun sepanjang permukaan atas, sehingga menghasilkan garis keperakan sempit yang biasa disebut piping (Coppens d'Eeckenbrugge dan Leal, 2003). Varietas yang memiliki duri hanya ditemukan pada CMPK, PK dan SBG. Hadiati (2011) menyatakan bahwa dengan dihasilkannya nenas tanpa duri, maka memudahkan petani dalam budidaya atau pemeliharaan serta pemanenan sehingga biaya tenaga kerja menjadi lebih rendah

Tabel 2. Deskripsi karakteristik daun nenas

\begin{tabular}{|c|c|c|c|c|c|c|c|c|}
\hline \multirow{3}{*}{ No } & \multirow{3}{*}{ Ket } & \multirow{3}{*}{ Karakter } & \multicolumn{6}{|c|}{ Hasil pengamatan varietas } \\
\hline & & & \multicolumn{5}{|c|}{ Kandidat } & \multirow{2}{*}{$\begin{array}{c}\text { Referensi } \\
\text { SBG } \\
\end{array}$} \\
\hline & & & Dole 14 & P1972 & MG01 & CMPK & PK & \\
\hline \multirow{3}{*}{$\begin{array}{c}3 \\
\text { QN }\end{array}$} & VG/ & Panjang daun & Pendek & Panjang & Pendek & Pendek & Panjang & Sedang \\
\hline & MS & Notasi & (3) & $(7)$ & (3) & (3) & $(7)$ & $(5)$ \\
\hline & $1-\mathrm{T}$ & Nilai Tengah $^{\mathrm{a}}$ & $66.955 \mathrm{c}$ & $80.964 a$ & $65.233 \mathrm{c}$ & $64.036 \mathrm{c}$ & $80.567 \mathrm{a}$ & $74.446 \mathrm{~b}$ \\
\hline \multirow{3}{*}{$\begin{array}{c}4 \\
\text { QN } \\
(*)\end{array}$} & VG/ & Lebar daun & Sempit & Luas & Sempit & Sedang & Luas & Luas \\
\hline & MS & Notasi & (3) & $(7)$ & (3) & (5) & $(7)$ & $(7)$ \\
\hline & $1-\mathrm{T}$ & Nilai Tengah $^{\mathrm{a}}$ & $4.218 \mathrm{c}$ & $5.055 \mathrm{a}$ & $4.317 \mathrm{cb}$ & $4.650 \mathrm{~b}$ & $5.258 \mathrm{a}$ & $5.154 \mathrm{a}$ \\
\hline \multirow{2}{*}{$\begin{array}{c}5 \\
\text { QN } \\
(*)\end{array}$} & \multirow{2}{*}{$\begin{array}{l}\text { VG } \\
1-T\end{array}$} & $\begin{array}{l}\text { Warna hjau di } \\
\text { sisi atas daun }\end{array}$ & Terang & Sedang & Sedang & Sedang & Gelap & Sedang \\
\hline & & Notasi & (3) & (5) & (5) & (5) & (7) & (5) \\
\hline \multirow{2}{*}{$\begin{array}{c}6 \\
\text { QN } \\
(*)\end{array}$} & $\mathrm{VG}$ & Warna antosianin & Tidak ada & Tidak ada & Sedang & Kuat & Tidak ada & Sedang \\
\hline & $1-\mathrm{T}$ & Notasi & (1) & (1) & (5) & (7) & (1) & (5) \\
\hline
\end{tabular}


Bul. Agrohorti 1 (4) : 83 - 93 (2013)

\begin{tabular}{|c|c|c|c|c|c|c|c|c|}
\hline \multirow{3}{*}{ No } & \multirow{3}{*}{ Ket } & \multirow{3}{*}{ Karakter } & \multicolumn{6}{|c|}{ Hasil pengamatan varietas } \\
\hline & & & \multicolumn{5}{|c|}{ Kandidat } & \multirow{2}{*}{$\frac{\text { Referensi }}{\text { SBG }}$} \\
\hline & & & Dole 14 & P1972 & MG01 & CMPK & PK & \\
\hline \multirow[t]{2}{*}{$\begin{array}{c}7 \\
\text { QN }\end{array}$} & \multirow[t]{2}{*}{$\begin{array}{l}\text { VG } \\
1-T\end{array}$} & $\begin{array}{l}\text { Kepadatan } \\
\text { trikoma di sisi } \\
\text { bawah daun }\end{array}$ & Tidak ada & Tidak ada & Tidak ada & Tidak ada & Tidak ada & Tidak ada \\
\hline & & Notasi & (1) & $(1)$ & (1) & (1) & (1) & (1) \\
\hline \multirow{2}{*}{$\begin{array}{c}8 \\
\mathrm{QL} \\
(*)\end{array}$} & \multirow{2}{*}{$\begin{array}{l}\text { VG } \\
1-T\end{array}$} & Keadaan marjin & Tidak ada & Tidak ada & Ada & Tidak ada & Tidak ada & Tidak ada \\
\hline & & Notasi & (1) & (1) & (9) & (1) & (1) & (1) \\
\hline \multirow{2}{*}{$\begin{array}{c}9 \\
\mathrm{QL} \\
\end{array}$} & VG & Daun: duri & Tidak ada & Tidak ada & Tidak ada & Ada & Ada & Ada \\
\hline & $1-\mathrm{T}$ & Notasi & $(1)$ & $(1)$ & $(1)$ & (9) & (9) & $(9)$ \\
\hline \multirow{2}{*}{$\begin{array}{c}10 \\
\text { QN }\end{array}$} & VG & Kepadatan duri & - & - & - & Jarang & Jarang & Jarang \\
\hline & $1-\mathrm{T}$ & Notasi & - & - & - & (1) & (1) & (1) \\
\hline \multirow[t]{2}{*}{$\begin{array}{c}11 \\
\mathrm{PQ}\end{array}$} & \multirow[t]{2}{*}{$\begin{array}{l}\text { VG } \\
1-\mathrm{T}\end{array}$} & $\begin{array}{l}\text { posisi duri di } \\
\text { marjin }\end{array}$ & - & - & - & $\begin{array}{l}\text { Didasar } \\
\text { dan } \\
\text { puncak }\end{array}$ & $\begin{array}{l}\text { Didasar } \\
\text { dan } \\
\text { puncak }\end{array}$ & $\begin{array}{l}\text { Didasar } \\
\text { dan } \\
\text { puncak }\end{array}$ \\
\hline & & Notasi & - & - & - & (3) & (3) & $(3)$ \\
\hline \multirow{2}{*}{$\begin{array}{l}12 \\
\mathrm{PQ}\end{array}$} & \multirow{2}{*}{$\begin{array}{l}\text { VG } \\
1-\mathrm{T}\end{array}$} & Warna duri & - & - & - & $\begin{array}{l}\text { Kuning } \\
\text { kehijauan }\end{array}$ & $\begin{array}{c}\text { Kuning } \\
\text { kehijauan }\end{array}$ & $\begin{array}{c}\text { Kuning } \\
\text { kehijauan }\end{array}$ \\
\hline & & Notasi & - & - & - & (1) & (1) & (1) \\
\hline \multirow{2}{*}{$\begin{array}{l}13 \\
\text { QN } \\
(*)\end{array}$} & \multirow{2}{*}{$\begin{array}{l}\text { VG } \\
1-\mathrm{T}\end{array}$} & Ukuran duri & - & - & - & Sedang & Sedang & Sedang \\
\hline & & Notasi & - & - & - & (3) & (3) & (3) \\
\hline
\end{tabular}

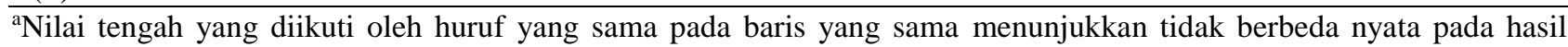
yang uji lanjut DMRT dengan taraf 5\%, QN: kuantitatif, QL: Kualitatif, VG: Pengamatan secara visual dengan pengamatan tunggal dari kelompok tanaman atau bagian tanaman, MS: Pengukuran sejumlah individu tanaman atau bagian tanaman, $(*)$ : karakter penting, 1-T: tahap Vegetatif .

\section{Karakter Generatif}

\section{a. Bunga}

Pengukuran pada karakter bunga menggunakan pengamatan visual. Tabel 3 menunjukkan ukuran braktea bunga varietas yang berbeda dengan varietas SBG adalah varietas P1972 dan MG 01 yang memiliki ukuran braktea yang lebih kecil. Karakter bunga pada beberapa varietas terdapat perbedaan yaitu seperti warna puncak mahkota bunga, rata-rata memiliki warna biru ungu kecuali varietas Dole 14 dan P1972 yang memiliki warna merah ungu. Pengamatan visual pada karakter panjang benang sari dan panjang putik terdapat banyak variasi. Varietas CMPK dan SBG memiliki panjang benang sari yang lebih pendek dari yang lain. Varietas Dole 14 dan P1972 memiliki panjang tangkai putik yang lebih panjang dari varietas yang lain.

Tabel 3. Deskripsi karakteristik bunga enam varietas nenas

\begin{tabular}{|c|c|c|c|c|c|c|c|c|}
\hline \multirow{3}{*}{ No } & \multirow{3}{*}{ Ket } & \multirow{3}{*}{ Karakter } & \multicolumn{6}{|c|}{ Hasil pengamatan varietas } \\
\hline & & & \multicolumn{5}{|c|}{ Kandidat } & \multirow{2}{*}{$\frac{\text { Referensi }}{\text { SBG }}$} \\
\hline & & & Dole 14 & P1972 & MG01 & CMPK & PK & \\
\hline \multirow{2}{*}{$\begin{array}{l}14 . \\
\text { QN } \\
(*)\end{array}$} & \multirow{2}{*}{$\begin{array}{l}\text { VG } \\
2-A\end{array}$} & $\begin{array}{l}\text { Ukuran braktea } \\
\text { bunga }\end{array}$ & Sedang & Kecil & Kecil & Sedang & Sedang & Sedang \\
\hline & & Notasi & $(1)$ & $(2)$ & (2) & $(2)$ & $(2)$ & (2) \\
\hline \multirow[t]{2}{*}{$\begin{array}{l}15 . \\
\text { QL }\end{array}$} & \multirow[t]{2}{*}{$\begin{array}{l}V G \\
2-A\end{array}$} & $\begin{array}{l}\text { Mahkota: } \\
\text { warna puncak }\end{array}$ & $\begin{array}{c}\text { Merah } \\
\text { ungu }\end{array}$ & $\begin{array}{c}\text { Merah } \\
\text { ungu }\end{array}$ & Biru ungu & $\begin{array}{l}\text { Biru } \\
\text { ungu }\end{array}$ & Biru ungu & Biru ungu \\
\hline & & Notasi & $(2)$ & $(2)$ & (1) & $(1)$ & (1) & (1) \\
\hline \multirow{2}{*}{$\begin{array}{l}16 . \\
\text { QN }\end{array}$} & $\begin{array}{l}\text { VG/ } \\
\text { MS }\end{array}$ & $\begin{array}{l}\text { Panjang } \\
\text { mahkota }\end{array}$ & Sedang & Sedang & Sedang & Sedang & Sedang & Sedang \\
\hline & 2-A & Notasi & (2) & (2) & (2) & (2) & (2) & (2) \\
\hline
\end{tabular}




\begin{tabular}{|c|c|c|c|c|c|c|c|c|}
\hline \multirow{3}{*}{ No } & \multirow{3}{*}{ Ket } & \multirow{3}{*}{ Karakter } & \multicolumn{6}{|c|}{ Hasil pengamatan varietas } \\
\hline & & & \multicolumn{5}{|c|}{ Kandidat } & \multirow{2}{*}{$\frac{\text { Referensi }}{\text { SBG }}$} \\
\hline & & & Dole 14 & P1972 & MG01 & CMPK & PK & \\
\hline \multirow{2}{*}{$\begin{array}{l}17 . \\
\text { QN }\end{array}$} & \multirow{2}{*}{$\begin{array}{l}\text { VG } \\
2-A\end{array}$} & $\begin{array}{l}\text { Benang sari: } \\
\text { panjang }\end{array}$ & Sedang & Sedang & Sedang & Pendek & Sedang & Pendek \\
\hline & & Notasi & (2) & (2) & (2) & (1) & (2) & (1) \\
\hline \multirow{2}{*}{$\begin{array}{l}18 . \\
\text { QN }\end{array}$} & \multirow{2}{*}{$\begin{array}{l}\text { VG } \\
2-A\end{array}$} & $\begin{array}{l}\text { Tangkai putik: } \\
\text { panjang }\end{array}$ & Panjang & Panjang & Sedang & Sedang & Sedang & Sedang \\
\hline & & Notasi & (3) & (3) & (2) & (2) & (2) & (2) \\
\hline
\end{tabular}

QN: Kuantitatif, QL: Kualitatif, VG: Pengamatan secara visual dengan pengamatan tunggal dari kelompok tanaman atau bagian tanaman, MS: Pengukuran sejumlah individu tanaman atau bagian tanaman, $\left.{ }^{*}\right)$ : Karakter penting, 2-A: Tahap Antesis.

\section{b. Tangkai dan Buah}

Karakter idiotipe nenas antara lain adalah bobot buah $1.0-1.3 \mathrm{~kg}$, PTT $>16^{\circ}$ Brix, mahkota buah tegak dan proporsional, warna daging buah kuning sampai jingga, daging buah renyah, hati kecil, mata datar, umur simpan panjang, responsif terhadap induksi pembungaan, dan tidak memiliki tulang daun (Sobir dan Naibaho, 2010). Karakter idiotipe ini menjadi prioritas dalam pengembangan varietas unggul nenas.

Buah nenas dipanen pada saat kematangan kurang lebih $30 \%$, hal ini disebabkan jika nenas dipanen $>30 \%$ akan diserang oleh hama musang karena keenam varietas ini memiliki aroma yang baik, sedangkan jika dipanen muda, warna buah pada saat matang akan terlihat pucat. Sabari et al. (2006) menyatakan bahwa pada Nenas Sampit (jenis smooth cayenne) menunjukkan bahwa nenas Sampit untuk konsumsi segar dapat dipanen pada > breaker 25\% matang dengan daging buah 69.92\% dan nisbah PTT atau asam $18.9 \%$, buah segar tahan simpan 4 hari pada kondisi kamar dan 6 hari pada suhu $15^{\circ} \mathrm{C}$.

Tabel 4 menunjukkan Pengamatan warna buah nenas pada saat belum masak dari keenam varietas diperoleh bahwa pada varietas Dole 14 dan PK memiliki warna hijau muda. Varietas P1972, MG 01 dan SBG memiliki warna buah pada saat belum masak berwarna hijau tua dan varietas CMPK memiliki warna hijau tua kehitaman. Warna buah belum masak pada varietas SBG belum terdaftarkan ke dalam daftar warna buah belum masak (nomer karakter 19) pada UPOV. Warna utama pada saat masak pada keenam varietas tidak berbeda yaitu berwarna kuning sedang.

Pengamatan pada karakter tangkai buah memiliki perbedaan satu sama lain. Varietas Dole 14 memiliki tangkai buah pendek dengan diameter kecil. Varietas P1972 memiliki panjang tangkai sedang dengan diameter besar. Varietas MG 01 memiliki panjang tangkai tinggi dengan diameter kecil. Varietas CMPK memiliki panjang tangkai tinggi dengan diameter sedang. Varietas PK memiliki tangkai pendek dengan diameter besar. Varietas SBG memiliki tangkai ukuran panjang dengan diameter sedang.

Pengamatan tangkai buah nenas sangat penting karena pada karakter tangkai buah dengan diameter sempit dan ukuran tangkai tinggi serta karakter bagian buah yang besar dapat terjadi patah tangkai yang terdapat dibeberapa varietas yaitu MG 01 dan CMPK karena tidak dapat menopang buah dan crown yang mempunyai bobot besar.Jumlah mahkota pada keenam varietas memiliki masing-masing satu mahkota buah. Namun pada varietas SBG terdapat nenas dengan 2 mahkota yang merupakan tipe simpang (off-type). Mahkota untuk varietas Dole 14, P1972 dan PK memiliki letak yang tegak, sedangkan pada tiga varietas lain memiliki letak yang semi tegak karena mempunyai ukuran mahkota buah yang besar dan menyebar.

Pengamatan visual pada bentuk buah menunjukkan pada varietas Dole 14 dan MG 01 memiliki bentuk bundar, sedangkan keempat varietas yang lain memiliki bentuk bulat panjang (elips). Pengukuran pada panjang dan diameter buah menunjukkan bahwa varietas yang lebih panjang dan diameter lebih besar adalah PK dan SBG. Tinggi tanaman, jumlah daun, dan lebar daun berkorelasi positif dan nyata dengan diameter buah (Nasution 2010). Sedangkan varietas Dole 14, MG 01 memiliki ukuran panjang buah yang pendek dan lebar ukuran sempit. Varietas P1972 memiliki panjang buah yang sama dengan varietas SBG dan PK, namun berdiameter sedang. varietas CMPK mempunyai ukuran panjang dan diameter buah sedang. Pengukuran 
pada ukuran buah menunjukkan varietas Dole 14 dan MG 01 memiliki ukuran kecil, sedangkan varietas PK, P1972 dan SBG memiliki ukuran buah yang besar.

Profil buah untuk keenam varietas yaitu datar yang merupakan salah satu dari penciri nenas kultivar smooth cayyene, dengan ukuran besar kecuali pada varietas SBG (kecil) dan CMPK (sedang). Terdapat perbedaan karakter pada mata buah nenas MG 01 yang memiliki bintik hitam. Pada varietas Dole 14, P1972, MG 01, dan PK memiliki warna daging buah kuning sedang atau kuning keemasan, sedangkan varietas CMPK dan SBG memiliki warna daging buah kuning keputihan. Hampir semua dari varietas ini memiliki kepadatan daging yang sedang, namun pada varietas SBG dan CMPK lebih terlihat longgar pada daging buahnya. Pada varietas P1972 terdapat retak yang ditemukan pada tanaman yang ditanam dengan tingkat keretakan yang berbeda. Hal ini menunjukkan bahwa varietas P1972 rentan terhadap keretakan buah. Lima varietas yang lain tidak ditemukan keretakan buah.

Diameter tengah buah atau diameter hati nenas pada varietas MG 01, dan Dole 14 memiliki ukuran yang lebih kecil dibanding varietas yang lain, sedangkan diameter hati nenas yang paling besar adalah varietas CMPK. Hati nenas yang besar merupakan karakter yang tidak diinginkan karena hati nenas keras dan tidak dapat dikonsumsi. Pengamatan pada kekukuhan menunjukkan varietas Dole 14 dan MG 01 mempunyai kekukuhan yang padat, sedangkan SBG dan CMPK memiliki kekukuhan yang lembut karena memiliki kandungan air yang lebih tinggi.
Smooth cayenne mempunyai daging berwarna kuning pucat, lembut, juicy, dengan nilai kemanisan $13^{\circ}$ sampai $19^{\circ}$ brix dan nilai keasaman yang tergantung kondisi lingkungan serta rendah asam askorbat (Chan et al., 2003). Pengukuran Total asam terlarut menggunakan sari buah nenas $10 \mathrm{ml}$ yang diencerkan sampai $100 \mathrm{ml}$ hasilnya menunjukan meq per $100 \mathrm{ml}$ jus (meq $100^{-1} \mathrm{ml}^{-1}$ ). Varietas SBG mempunyai total asam terlarut yang lebih tinggi dari varietas yang lainnya. Sedangkan varietas dengan total asam terlarut yang rendah adalah varietas P1972, Dole 14, dan PK. Hasil pengukuran nilai kemanisan menunjukkan varietas SBG mempunyai tingkat kemanisan yang tinggi dibanding yang lain. Varietas P1972 memiliki tingkat kemanisan yang rendah.

Pengamatan dengan menggunakan uji organoleptik menggunakan 10 responden dilakukan pada pengamatan keberseratan (kandungan serat), aroma, dan keberairan (juiciness). Hasil uji organoleptik menunjukkan bahwa varietas MG 01 mempunyai kandungan serat yang paling tinggi, sedangkan SBG memiliki kandungan serat yang paling rendah. Pengujian kandungan air varietas SBG memiliki kandungan air yang tinggi (bersifat juicy), sedangkan varietas yang lainnya sedang. Nasution et al. (2010) menyatakan bahwa nenas dengan kadar air yang tinggi kurang baik untuk dijadikan sebagai nenas segar (buah meja), sehingga perbaikan karakter pada nenas subang perlu dilakukan.

Pada uji aroma menghasilkan P1972 memiliki aroma yang kuat, sedangkan varietas CMPK memiliki aroma yang lemah. Nenas merupakan salah satu buah tropis yang paling dihargai karena aroma yang menarik dan rasa yang baik (Mohammad et al., 2010).

Tabel 4. Deskripsi keunikan karakteristik bagian tangkai dan buah enam varietas nenas

\begin{tabular}{|c|c|c|c|c|c|c|c|c|}
\hline \multirow{3}{*}{ No } & \multirow{3}{*}{ Ket } & \multirow{3}{*}{ Karakter } & \multicolumn{6}{|c|}{ Hasil pengamatan varietas } \\
\hline & & & \multicolumn{5}{|c|}{ Kandidat } & \multirow{2}{*}{$\begin{array}{c}\text { Referensi } \\
\text { SBG }\end{array}$} \\
\hline & & & Dole 14 & P1972 & MG01 & CMPK & PK & \\
\hline \multirow[t]{2}{*}{$\begin{array}{l}19 . \\
\text { PQ }\end{array}$} & \multirow[t]{2}{*}{$\begin{array}{l}\text { VG } \\
3-\mathrm{I}\end{array}$} & $\begin{array}{l}\text { Buah belum } \\
\text { masak : warna }\end{array}$ & $\begin{array}{l}\text { Hijau } \\
\text { muda }\end{array}$ & $\begin{array}{l}\text { Hijau } \\
\text { Tua }\end{array}$ & $\begin{array}{l}\text { Hijau } \\
\text { tua }\end{array}$ & $\begin{array}{c}\text { Hijau tua } \\
\text { kehitama } \\
\text { n }\end{array}$ & $\begin{array}{l}\text { Hijau } \\
\text { muda }\end{array}$ & Hijau tua \\
\hline & & Notasi & (2) & (3) & (3) & (9) & (2) & (3) \\
\hline \multirow{3}{*}{$\begin{array}{l}21 . \\
\text { QN } \\
(*)\end{array}$} & $\begin{array}{c}\mathrm{VG} \\
/\end{array}$ & $\begin{array}{l}\text { Tangkai buah: } \\
\text { panjang }\end{array}$ & Pendek & Sedang & Panjang & Panjang & Pendek & Panjang \\
\hline & \multirow{2}{*}{$\begin{array}{c}\text { MS } \\
4- \\
\text { M }\end{array}$} & Notasi & (1) & (2) & (3) & (3) & (1) & (3) \\
\hline & & Nilai Tengah $^{\mathrm{a}}$ & $15.155 \mathrm{c}$ & $19.291 b$ & $24.150 \mathrm{a}$ & $22.243 \mathrm{a}$ & $15.008 \mathrm{c}$ & $22.908 \mathrm{a}$ \\
\hline
\end{tabular}




\begin{tabular}{|c|c|c|c|c|c|c|c|c|}
\hline \multirow{3}{*}{ No } & \multirow{3}{*}{ Ket } & \multirow{3}{*}{ Karakter } & \multicolumn{6}{|c|}{ Hasil pengamatan varietas } \\
\hline & & & \multicolumn{5}{|c|}{ Kandidat } & \multirow{2}{*}{$\frac{\text { Referensi }}{\text { SBG }}$} \\
\hline & & & Dole 14 & $\mathrm{P} 1972$ & MG01 & CMPK & PK & \\
\hline \multirow{3}{*}{$\begin{array}{l}22 . \\
\text { QN }\end{array}$} & \multirow{3}{*}{$\begin{array}{c}\mathrm{VG} \\
/ \\
\mathrm{MS} \\
4- \\
\mathrm{M} \\
\end{array}$} & $\begin{array}{l}\text { Tangkai buah: } \\
\text { diameter }\end{array}$ & Kecil & Besar & Kecil & Sedang & Besar & sedang \\
\hline & & Notasi & $(1)$ & $(3)$ & $(1)$ & (2) & (3) & (2) \\
\hline & & Nilai Tengah $^{\mathrm{a}}$ & $1.778 \mathrm{~d}$ & $2.499 \mathrm{ab}$ & $1.805 \mathrm{dc}$ & $2.281 \mathrm{~b}$ & $2.573 \mathrm{a}$ & $2.022 \mathrm{c}$ \\
\hline \multirow[t]{2}{*}{28.} & \multirow[b]{2}{*}{ VG } & Mahkota: jumlah & Satu & Satu & Satu & Satu & Satu & Satu \\
\hline & & Notasi & $(1)$ & $(1)$ & $(1)$ & $(1)$ & $(1)$ & $(1)$ \\
\hline \multirow[t]{2}{*}{$\begin{array}{l}29 . \\
\text { QN }\end{array}$} & \multirow{2}{*}{$\begin{array}{l}\text { VG } \\
4- \\
\mathrm{M}\end{array}$} & Mahkota: letak & $\begin{array}{l}\text { Tegak } \\
\text { lurus }\end{array}$ & $\begin{array}{l}\text { Tegak } \\
\text { lurus }\end{array}$ & $\begin{array}{l}\text { Semi } \\
\text { tegak }\end{array}$ & $\begin{array}{c}\text { Semi } \\
\text { tegak }\end{array}$ & $\begin{array}{l}\text { Tegak } \\
\text { lurus }\end{array}$ & $\begin{array}{l}\text { Semi } \\
\text { tegak }\end{array}$ \\
\hline & & Notasi & $(1)$ & $(1)$ & $(2)$ & $(2)$ & $(1)$ & $(2)$ \\
\hline \multirow[t]{2}{*}{30.} & \multirow{2}{*}{$\begin{array}{l}\mathrm{VG} \\
4-\mathrm{M} \\
\end{array}$} & Mahkota: ukuran & Kecil & Sedang & Besar & Besar & Sedang & Besar \\
\hline & & Notasi & $(3)$ & (5) & $(7)$ & $(7)$ & (5) & $(7)$ \\
\hline \multirow{2}{*}{$\begin{array}{l}31 . \\
\text { PQ } \\
(*)\end{array}$} & \multirow{2}{*}{$\begin{array}{l}\text { VG } \\
4-M\end{array}$} & Buah: bentuk & Bundar & $\begin{array}{c}\text { Bulat } \\
\text { panjang }\end{array}$ & Bundar & $\begin{array}{c}\text { Bulat } \\
\text { panjang }\end{array}$ & $\begin{array}{c}\text { Bulat } \\
\text { panjang }\end{array}$ & $\begin{array}{c}\text { Bulat } \\
\text { panjang }\end{array}$ \\
\hline & & Notasi & $(5)$ & $(4)$ & $(5)$ & (4) & (4) & (4) \\
\hline \multirow{3}{*}{$\begin{array}{l}32 . \\
\text { QN } \\
(*)\end{array}$} & VG/ & Buah: panjang & Pendek & Panjang & Pendek & Sedang & Panjang & Panjang \\
\hline & MS & Notasi & (3) & $(7)$ & (3) & $(5)$ & $(7)$ & (7) \\
\hline & 4-M & Nilai Tengah $^{\mathrm{a}}$ & $8.661 \mathrm{~b}$ & $11.588 \mathrm{a}$ & $9.067 \mathrm{~b}$ & $10.221 \mathrm{ab}$ & $11.494 \mathrm{a}$ & $11.606 \mathrm{a}$ \\
\hline \multirow{3}{*}{$\begin{array}{l}33 . \\
\text { QN } \\
(*)\end{array}$} & VG/ & Buah: diameter & Sempit & Sedang & Sempit & Sedang & Besar & Besar \\
\hline & MS & Notasi & $(1)$ & (3) & (1) & (3) & (5) & (5) \\
\hline & 4-M & Nilai Tengah $^{\mathrm{a}}$ & $10.027 \mathrm{~b}$ & $10.924 \mathrm{ab}$ & $10.087 \mathrm{~b}$ & $10.499 \mathrm{ab}$ & $11.406 \mathrm{a}$ & $11.114 \mathrm{a}$ \\
\hline \multirow{2}{*}{$\begin{array}{l}34 . \\
\text { PQ } \\
(*)\end{array}$} & \multirow{2}{*}{$\begin{array}{l}\text { VG } \\
4-M\end{array}$} & $\begin{array}{l}\text { Buah: warna } \\
\text { utama }\end{array}$ & $\begin{array}{l}\text { Kuning } \\
\text { sedang }\end{array}$ & $\begin{array}{l}\text { Kuning } \\
\text { sedang }\end{array}$ & $\begin{array}{l}\text { Kuning } \\
\text { sedang }\end{array}$ & $\begin{array}{l}\text { Kuning } \\
\text { sedang }\end{array}$ & $\begin{array}{l}\begin{array}{l}\text { Kuning } \\
\text { sedang }\end{array} \\
\end{array}$ & $\begin{array}{l}\text { Kuning } \\
\text { sedang }\end{array}$ \\
\hline & & Notasi & $(6)$ & (6) & (6) & $(6)$ & $(6)$ & (6) \\
\hline 35. & MS/ & Buah: ukuran & Kecil & Besar & Kecil & Sedang & Besar & Besar \\
\hline QN & VG & Notasi & $(3)$ & $(7)$ & (3) & (5) & $(7)$ & $(7)$ \\
\hline$(*)$ & 4-M & Nilai Tengah $^{\mathrm{a}}$ & $526.0 \mathrm{~b}$ & $829.3 a$ & $582.3 \mathrm{~b}$ & $722.1 \mathrm{ab}$ & $945.3 \mathrm{a}$ & $920.5 \mathrm{a}$ \\
\hline \multirow{2}{*}{$\begin{array}{l}36 \\
. \mathrm{Q} \\
\mathrm{N} \\
(*)\end{array}$} & \multirow{2}{*}{$\begin{array}{l}\text { VG } \\
4-\mathrm{M}\end{array}$} & $\begin{array}{l}\text { Buah: ukuran } \\
\text { mata tunas }\end{array}$ & besar & besar & besar & Sedang & besar & Kecil \\
\hline & & Notasi & (7) & (7) & (7) & $(5)$ & (7) & (3) \\
\hline \multirow{2}{*}{$\begin{array}{l}37 . \\
\text { QN } \\
(*)\end{array}$} & \multirow{2}{*}{$\begin{array}{l}\text { VG } \\
4-M\end{array}$} & Buah: profil mata & Datar & Datar & Datar & Datar & Datar & Datar \\
\hline & & Notasi & (2) & (2) & (2) & (2) & (2) & (2) \\
\hline \multirow[t]{2}{*}{$\begin{array}{l}38 . \\
\text { QN }\end{array}$} & \multirow[t]{2}{*}{$\begin{array}{l}\text { VG } \\
4-M\end{array}$} & $\begin{array}{l}\text { Buah: } \\
\text { ketidakrata-an } \\
\text { warna mata }\end{array}$ & $\begin{array}{l}\text { Sangat } \\
\text { tidak } \\
\text { merata }\end{array}$ & $\begin{array}{l}\text { Sangat } \\
\text { tidak } \\
\text { merata }\end{array}$ & $\begin{array}{l}\text { Sangat } \\
\text { tidak } \\
\text { merata }\end{array}$ & $\begin{array}{l}\text { Sangat } \\
\text { tidak } \\
\text { merata }\end{array}$ & $\begin{array}{l}\text { Sangat } \\
\text { tidak } \\
\text { merata }\end{array}$ & $\begin{array}{l}\text { Sangat } \\
\text { tidak } \\
\text { merata }\end{array}$ \\
\hline & & Notasi & (3) & (3) & (3) & (3) & (3) & (3) \\
\hline $\begin{array}{l}39 . \\
\text { PQ }\end{array}$ & $\begin{array}{l}\text { VG } \\
4-M\end{array}$ & $\begin{array}{l}\text { Buah: warna } \\
\text { daging }\end{array}$ & $\begin{array}{l}\text { Kuning } \\
\text { sedang }\end{array}$ & $\begin{array}{l}\text { Kuning } \\
\text { sedang }\end{array}$ & $\begin{array}{l}\text { Kuning } \\
\text { sedang }\end{array}$ & $\begin{array}{c}\text { Kuning } \\
\text { keputiha } \\
n\end{array}$ & $\begin{array}{l}\text { Kuning } \\
\text { sedang }\end{array}$ & $\begin{array}{c}\text { Kuning } \\
\text { keputiha } \\
n\end{array}$ \\
\hline & & Notasi & (3) & (3) & (3) & (1) & (3) & (1) \\
\hline 40. & VG/ & $\begin{array}{l}\text { Buah: diameter } \\
\text { tengah }\end{array}$ & Kecil & Kecil & Sedang & Besar & Sedang & Sedang \\
\hline & $\begin{array}{l}\mathrm{MS} \\
4-\mathrm{M}\end{array}$ & Notasi & (3) & (3) & (5) & $(7)$ & (5) & (5) \\
\hline & 4-M & Nilai Tengah $^{\mathrm{a}}$ & $2.202 \mathrm{c}$ & $2.065 \mathrm{c}$ & $2.546 \mathrm{ab}$ & $2.687 \mathrm{a}$ & $2.290 \mathrm{bc}$ & $2.541 \mathrm{ab}$ \\
\hline 41. & $\begin{array}{l}\text { VG } \\
4-M\end{array}$ & $\begin{array}{l}\text { Daging: } \\
\text { ketidakrataan } \\
\text { warna }\end{array}$ & $\begin{array}{l}\text { Cukup } \\
\text { merata }\end{array}$ & $\begin{array}{l}\text { Cukup } \\
\text { merata }\end{array}$ & $\begin{array}{l}\text { Cukup } \\
\text { merata }\end{array}$ & $\begin{array}{l}\text { Cukup } \\
\text { merata }\end{array}$ & $\begin{array}{l}\text { Cukup } \\
\text { merata }\end{array}$ & $\begin{array}{l}\text { Cukup } \\
\text { merata }\end{array}$ \\
\hline & & Notasi & $(2)$ & $(2)$ & $(2)$ & $(2)$ & (2) & (2) \\
\hline
\end{tabular}


Bul. Agrohorti 1 (4) : 83 - 93 (2013)

\begin{tabular}{|c|c|c|c|c|c|c|c|c|}
\hline \multirow{3}{*}{ No } & \multirow{3}{*}{ Ket } & \multirow{3}{*}{ Karakter } & \multicolumn{6}{|c|}{ Hasil pengamatan varietas } \\
\hline & & & \multicolumn{5}{|c|}{ Kandidat } & \multirow{2}{*}{$\begin{array}{c}\text { Referensi } \\
\text { SBG } \\
\end{array}$} \\
\hline & & & Dole 14 & P1972 & MG01 & CMPK & PK & \\
\hline \multirow{2}{*}{$\begin{array}{l}42 . \\
\text { QN } \\
(*)\end{array}$} & \multirow{2}{*}{$\begin{array}{l}\text { VG } \\
4-\mathrm{M}\end{array}$} & $\begin{array}{l}\text { Daging: } \\
\text { kepadatan }\end{array}$ & Sedang & Sedang & Sedang & Longgar & Sedang & Longgar \\
\hline & & Notasi & (2) & $(2)$ & $(2)$ & $(1)$ & $(2)$ & $(1)$ \\
\hline \multirow{3}{*}{$\begin{array}{l}43 . \\
\text { QN }\end{array}$} & \multirow{3}{*}{$\begin{array}{l}\text { MS } \\
4-M\end{array}$} & $\begin{array}{l}\text { Daging: } \\
\text { kekukuhan }\end{array}$ & Padat & Sedang & Padat & Lembut & Sedang & Lembut \\
\hline & & Notasi & (7) & (5) & (7) & (3) & (5) & (3) \\
\hline & & Nilai Tengah $^{\mathrm{a}}$ & $65.56 \mathrm{~d}$ & $76.39 \mathrm{c}$ & $70.67 \mathrm{dc}$ & 88.00ab & $81.03 b c$ & $95.01 \mathrm{a}$ \\
\hline \multirow{3}{*}{$\begin{array}{l}44 . \\
\text { QN }\end{array}$} & \multirow{3}{*}{$\begin{array}{l}\text { VG } \\
4-M\end{array}$} & Daging: berserat & Sedang & Sedang & Tinggi & sedang & Sedang & Sedikit \\
\hline & & Notasi & (2) & $(2)$ & (3) & $(2)$ & (2) & $(1)$ \\
\hline & & Uji organoleptik $^{\mathrm{b}}$ & 6 & 8 & 9 & 6 & 7 & 5 \\
\hline \multirow{3}{*}{45.} & \multirow{3}{*}{$\begin{array}{l}\text { VG } \\
4-M\end{array}$} & Daging: aroma & Sedang & Tinggi & Sedang & Sedang & Sedang & Sedang \\
\hline & & Notasi & (2) & (3) & (2) & (2) & (2) & (2) \\
\hline & & Uji organoleptik $^{\mathrm{b}}$ & 5 & 7 & 4 & 5 & 7 & 8 \\
\hline \multirow{3}{*}{$\begin{array}{l}46 . \\
\text { QN } \\
(*)\end{array}$} & \multirow{3}{*}{$\begin{array}{l}\mathrm{VG} \\
4-\mathrm{M}\end{array}$} & Daging: berair & Sedang & Sedang & Sedang & Sedang & Sedang & Tinggi \\
\hline & & Notasi & $(2)$ & (2) & $(2)$ & (2) & (2) & (3) \\
\hline & & Uji organoleptik $^{\mathrm{b}}$ & 7 & 8 & 7 & 8 & 7 & 9 \\
\hline \multirow{3}{*}{$\begin{array}{l}47 . \\
\text { QN }\end{array}$} & \multirow{3}{*}{$\begin{array}{l}\text { MS } \\
4-M\end{array}$} & $\begin{array}{l}\text { Daging: } \\
\text { keasaman }\end{array}$ & Rendah & Rendah & Sedang & Sedang & Rendah & Tinggi \\
\hline & & Notasi & (3) & (3) & $(5)$ & $(5)$ & (3) & $(7)$ \\
\hline & & Nilai Tengah $^{\mathrm{a}}$ & $57.716 \mathrm{bc}$ & $51.665 \mathrm{c}$ & $72.107 \mathrm{ab}$ & $67.794 \mathrm{ab}$ & $62.240 \mathrm{abc}$ & $75.274 a$ \\
\hline \multirow{3}{*}{$\begin{array}{l}48 . \\
\text { QN } \\
(*)\end{array}$} & \multirow{3}{*}{$\begin{array}{l}\text { MS } \\
4-M\end{array}$} & $\begin{array}{l}\text { Daging: } \\
\text { kemanisan }\end{array}$ & Sedang & Rendah & Sedang & Sedang & Sedang & Tinggi \\
\hline & & Notasi & (5) & (3) & (5) & (5) & $(5)$ & $(7)$ \\
\hline & & Nilai Tengah $^{\mathrm{a}}$ & $15.357 \mathrm{ab}$ & $15.075 \mathrm{~b}$ & $16.757 \mathrm{ab}$ & $17.058 \mathrm{ab}$ & $16.882 \mathrm{ab}$ & $19.525 \mathrm{a}$ \\
\hline
\end{tabular}

\section{Uji BUSS (Baru Unik Seragam Stabil)}

UU No. 29 Tahun 2000 tentang PVT menyatakan bahwa suatu varietas dianggap baru apabila pada saat penerimaan permohonan hak PVT, bahan perbanyakan atau hasil panen dari varietas tersebut belum pernah diperdagangkan lebih dari setahun, atau telah diperdagangkan di luar negeri tidak lebih dari empat tahun untuk tanaman semusim dan enam tahun untuk tanaman tahunan (Pasal 2 Ayat 2). Pengujian kebaruan menggunakan varietas SBG sebagai varietas referensi tidak dapat dikatakan baru karena varietas ini sudah dikenal luas dimasyarakat dan sebagai varietas unggul Indonesia. Varietas Dole 14, P1972, MG 01, CMPK dan PK dapat dikatakan baru di Indonesia karena belum dikenal masyarakat luas dan bahan tanaman varietas ini masih terbatas di Indonesia.

Suatu varietas dapat dikatakan unik jika memiliki perbedaan yang konsisten dan jelas dengan varietas yang lain (UPOV 2012). Menurut UU No. 29 Tahun 2000 tentang PVT, menyatakan bahwa suatu varietas dianggap unik jika varietas tersebut dapat dibedakan secara jelas dengan varietas lain yang keberadaannya sudah dikenal luas pada saat penerimaan permohonan hak PVT (Pasal 2 Ayat 3). Pada keenam varietas yang diuji terdapat keunikan atau perbedaan yang jelas pada masing-masing varietas. Keunikan tersebut dapat terlihat baik pada karakteristik yang diamati. Setiap varietas mempunyai keunikan masingmasing sehingga dapat dibedakan antara satu dengan yang lain.

Suatu varietas dapat dikatakan seragam bila suatu populasi ditetapkan standar diterima minimal 95\%, untuk ukuran sampel 25 tanaman jika terdapat 3 jenis off-type dapat dikatakan seragam (UPOV 2012). Menurut UU No. 29 Tahun 2000 tentang PVT, suatu varietas dianggap seragam apabila sifat-sifat utama atau penting pada varietas tersebut terbukti seragam meskipun 
bervariasi sebagai akibat dari cara tanam dan lingkungan yang berbeda-beda (Pasal 2 Ayat 4) Semua varietas yang diuji dapat dikatakan seragam karena hanya terdapat satu tipe simpang pada varietas SBG dengan 2 crown.

Pengalaman menunjukkan untuk berbagai jenis varietas jika suatu varietas terbukti seragam dapat dikatakan stabil (UPOV, 2012). Keenam varietas yang diuji dapat dikatakan telah stabil, karena keenam varietas tersebut terbukti telah seragam.

\section{KESIMPULAN}

Berdasarkan pengamatan keunikan dari enam varietas (Dole 14, P1972, MG 01, CMPK dan PK) jenis smooth cayenne yang digunakan yaitu 5 varietas kandidat dan 1 varietas referensi terlihat perbedaan. Perbedaan antara varietas kandidat dengan varietas referensi terdapat tujuh karakter pada bagian tanaman, enam karakter pada bagian daun, empat karakter pada bagian bunga, sembilan belas karakter pada bagian tangkai dan buah.

Keenam varietas dapat dinyatakan seragam. Tipe simpang hanya ditemukan pada satu tanaman dengan dua crown pada varietas Subang, jumlah tipe simpang yang ditemukan masih dibawah batas keseragaman yang telah ditetapkan. Keenam varietas yang diuji dapat dinyatakan telah stabil. PPU (Panduan Pengujian Umum) sudah dapat digunakan untuk melakukan uji keunikan karena jelas dan dapat menggambarkan karakter penting pada nenas. Keragaman keenam varietas ini cukup tinggi maka dapat digunakan sebagai varietas contoh dalam nenas jenis smooth cayenne.

Penyempurnaan pada UPOV dapat ditambahkan pada karakter warna buah pada saat belum masak (nomer karakter 19) pada warna buah varietas CMPK yaitu hijau tua kehitaman (notasi 9). Karakter lain yang dapat ditambahkan yaitu pada karakter warna dominan pada braktea, keberadaan bintik pada mata, kedalaman mata, pola putaran mata pada putaran terpanjang dan keberadaan biji karena terdapat perbedaan antar varietas. Keenam varietas yang diuji dapat digunakan sebagai varietas contoh dalam nenas jenis smooth cayenne.

\section{UCAPAN TERIMA KASIH}

Penulis menyampaikan terima kasih kepada pihak PKHT dan Pusat Perlindungan Varietas Tanaman yang telah memberikan dana hibah pada penelitian ini.

\section{DAFTAR PUSTAKA}

Chan YK, Coppens d'Eeckenbrugge G, Snewski. 2003. Breeding and Variety Improvement. Di dalam : Bartholomew DP, Pull RE, Rohrbach KG, Editor. The Pineapple, Botany, Production and Uses. USA(US): Cabi Publishing. Hlm 33-55.

[Deptan] Departemen Pertanian. 2013. Perkembangan produksi tanaman, nilai impor dan ekspor buah tahun 2012 [Internet]. [diunduh 05 Mei 2013] Tersedia pada: http://hortikultura.deptan.go.id.

Coppens d'Eeckenbrugge G, Leal F. 2003. Morphology, Anatomy and Taxonomy. Di dalam Bartholomew DP, Pull RE, Rohrbach KG, Editor. The Pineapple, Botany, Production and Uses. USA(US): Cabi Publishing. Hlm 1-12.

FAOSTAT. 2013. Pineapple Production 20072011 [Internet]. [2013 Jan 16]. [diunduh 05 Mei 2013]. Tersedia pada http://faostat.fao.org/site/567/ DesktopDefault.aspx?PageID=567\#ancor

Hadiati S, Yuliati S, Jumjunidang. 2011. Evaluasi pertumbuhan dan hasil beberapa kandidat varietas nenas rendah oksalat dan manis tanpa duri. J. Hort. Indonesia. 21(4):315323.

Mohammad GA, Andreas DH, Klaus DK. 2010. Isolation of polysaccharides from pineapple fruit pulp and their enzymatic liquifaction. International Food Research Journal. 17: 193-203

Nasution MA, Poerwanto R, Sobir, Surahman M, Trikoesoemaningtyas. 2010. Seleksi hasil persilangan antara 'queen' dan 'smooth cayenne' untuk perbaikan hasil dan mutu buah nenas. J. Hort. Indonesia. 1(1):10-16

Nasution MA. 2010. Analisis korelasi dan sidik lintas antara karakter morfologi dan komponen buah tanaman nenas (Ananas comosus L. Merr.). Crop Agro. 3(1):1-8

Nitrisari R, Sobir. 2002. Analisis keragaan morfologi dan kualitas buah populasi nenas (Ananas comosus (L.) Merr) queen di empat desa kabupaten Bogor. Didalam Sobir, Suwarto, Desta, editor. Bogor (ID): Prosiding Seminar Akademik Buahbuahan. 1(3):171-175 
UPOV. 2012. Guidelines For The Conduct of Tests for Distinctness, Uniformity, and Stability. France(FR); UPOV International.

Sabari SD, Suryanti, Sunarmani. 2006. Tingkat kematangan panen buah nenas sampit untuk kosumsi segar dan jam. J. Hort. Indonesia. 16(3) : 1-5
Sobir, Naibaho N. 2010. Program Pengembangan Nenas. IV1-27. Dalam Tim Pengarah dan Supervisor RUSNAS Buah, Editor. Peningkatan Daya Saing Buah Nasional Melalui Riset Strategis. Bogor (ID): IPB Press.

$\mathrm{Hlm}$

$1-27(\mathrm{IV})$. 